\title{
SYNTHESIS OF SILVER NANOPARTICLES USING BELUNTAS LEAF (Pluchea Indica L.) EXTRACT
}

\author{
Fatimah $^{1 *}$, Wahid Wahab ${ }^{1}$, Abdul Karim ${ }^{1}$ \\ ${ }^{1}$ Department of Chemistry, Faculty of Matemathics and Natural Science, Hasanuddin University \\ Jl. Perintis Kemerdekaan Km 10 Makassar \\ *Corresponding author: ima_costig@yahoo.co.id
}

\begin{abstract}
Abstrak. Sintesis nanopartikel perak dilakukan dengan menggunakan ekstrak daun Beluntas (Pluchea Indica $L$.) yang ramah lingkungan, untuk meminimalisir penggunaan pereduksi dari bahan kimia yang berbahaya bagi lingkungan. Sintesis dilakukan pada perbandingan volume larutan $\mathrm{AgNO}_{3}$ terhadap ekstrak beluntas 90:1. Proses pembentukan nanopartikel perak dipelajari dan dimonitor dengan menggunakan spektrofotometer UV-Vis. Hasil pengamatan menunjukkan bahwa nanopartikel perak yang terbentuk memiliki puncak absorbansi pada panjang gelombang sekitar 445,5 nm dengan absorbansi sebesar 3,437. Absorbansi semakin besar dengan bertambahnya waktu reaksi dari 1 jam hingga 168 jam. Berdasarkan hasil pengujian dengan menggunakan PSA, ukuran rata-rata nanopartikel perak yang didapatkan adalah 109,1 nm yang terdispersi antara 1,8 nm-127,3 nm.
\end{abstract}

Kata Kunci: Nanopartikel Perak, Sintesis, Daun Beluntas, UV-Vis, Particle Size Analyzer

\begin{abstract}
Synthesis of silver nanoparticles was carried out using Beluntas (Pluchea Indica L.) leaf extract as a friendly agent, to minimize the use of harmful chemicals. Synthesis was carried out with the volume ratio of $\mathrm{AgNO}_{3}$ solution to the beluntas leaf extract of 90:1. The process of forming silver nanoparticles was studied and monitored with UV-Vis spectrophotometer. The observations showed that silver nanoparticles formed had an absorbance peak at the wavelength of about 445,5 nm with an absorbance of 3,437. The absorbance value increased with the increasing reaction time from 1 hour to 168 hours. Based on the result of testing using PSA, the average size of silver nanoparticles was 109.1 $\mathrm{nm}$ which is dispersed between $1,8 \mathrm{~nm}-127,3 \mathrm{~nm}$.
\end{abstract}

Keywords: Silver Nanoparticles, Synthesis, Beluntas Leaf, UV-Vis, Particle Size Analyzer 


\section{INTRODUCTION}

Currently,

research

on nanoparticles is one of the most developed nanotechnology developments. Nanoparticles not just focus on how the application, but also on how to synthesize it. Nanoparticles are particles with a nanometer size, around 1-100 nm. Material with the structure of the nanoparticles are generally have different properties with the original structure (Fabiani, et. al., 2018). One of the materials synthesized as nanoparticles is silver because it can be applied in various fields of science and technology (Apriandanu, et. al., 2013). Silver also exhibits the highest electrical and thermal conductivities among all the metals (Kumar and Rani, 2013).

Silver nanoparticles have been widely used in various applications in the fields of dentistry, clothing, catalysis, mirrors, optics, photography, electronics, and the food industry (Shameli, et. al., 2012). Many chemicals are available for the synthesis of metal nanoparticles, but there is concerns about the use of these chemicals because they are highly toxic materials (Terenteva, et. al., 2015). Apart from the poisoning of these chemicals, the use of these chemicals is also not effective because it can cause losses for the synthesis of nanoparticles on an industrial scale. Because of this, various methods that have been developed by experts have emerged which are named "Green Nanotechnology" plant-based as a bioreductor for the synthesis of silver nanoparticles (Desna et. al., 2015). It is believed that Plant extracts can act as reducing and capping agents in the synthesis of nanoparticle due to the presence of bioactive compounds (Anjum and Abbasi, 2016).

Beluntas leaf (Pluchea indica L.) is a shrub of the Asteraceae group that has been known as traditional medicine. Roots of the plant contain stigmasterol, stigmasterol glycosides, 2-(prop-1-unil)-5(5,6 dihidroksi heksa-1,3-diunil)-thiofena and catechins (Widyawati, et. al., 2008), while the leaves contain hydroquinone, tannins, alkaloids, sterols and flavonoids (especially quercetin) (Desmiaty et, al., 2015).

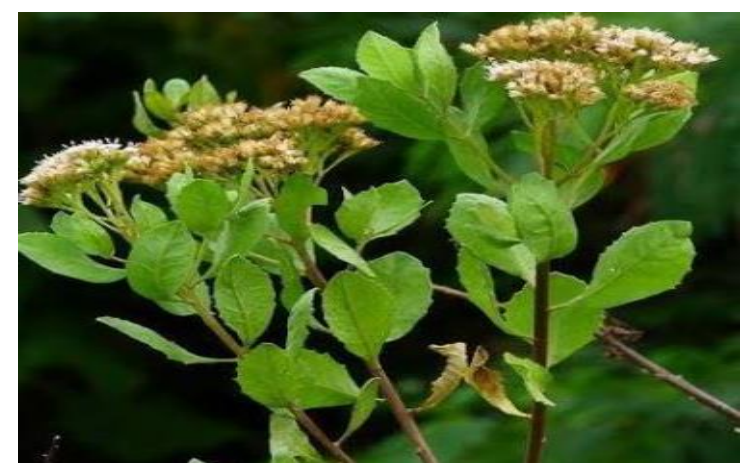

Figure 1. Beluntas leaf (Pluchea Indica L.)

This flavonoid content in Beluntas leaf has the potential as a reducing agents in the manufacture of silver nanoparticles.

\section{MATERIAL AND METHOD Instruments}

The instruments used included analytical scales, UV-Vis Spectrophotometer (Shimadzu UV-2600), Particle Size Analyzer (PSA) (Vasco), Multistirrer 15 (Velp Scientifica 218429), Drop Pipette, volume pipette, Erlenmeyer, beaker, measuring flask, stirring rod, bottle spray, and centrifuge.

\section{Materials}

The materials used were Beluntas (Pluchea indica L.) leaf, $\mathrm{AgNO}_{3}$, double distilled water, distilled water, whatmann paper No. 42, and aluminum foil. 


\section{Methods}

\section{Preparation of $\mathbf{1} \mathbf{m M}$ AgNO3 solution}

$1 \mathrm{mM} \mathrm{AgNO} 3$ solution was made by dissolving 0.085 grams of $\mathrm{AgNO}_{3}$ powder with double distilled water in $500 \mathrm{~mL}$ volumetric flask to the boundary mark and homogenized. This solution can be used directly and when it is not used, this solution is stored in the refrigerator.

\section{Preparation of beluntas leaf extract}

The part of the beluntas leaf used young leaf in fresh condition. The leaf were picked and then washed throughly with distilled water. After that, the leaf was cut into small pieces, 10 grams of the leaf was weighed and then boiled with $50 \mathrm{~mL}$ of double distilled water in a $250 \mathrm{~mL}$ beaker. In addition, the mixture was boiled and left for 5 minutes. After reaching room temperature, the aqueous was poured and filtered using whatmann paper no. 42. The extract can then be used directly for the synthesis process. The extract of beluntas leaves was stored in the refrigerator when not in use.

\section{Synthesis of Silver Nanoparticles using Beluntas Leaf Extract}

The synthesis of silver nanoparticles was carried out by mixing 1 $\mathrm{mM} \mathrm{AgNO} 3$ solution with the beluntas leaf extract. $1 \mathrm{~mL}$ of the extract was mixed into $90 \mathrm{~mL} \mathrm{AgNO}_{3}$ solution, then stirred for 2 hours. The change in color into a brownish solution indicated that silver nanoparticles have been formed.

\section{Characterization of Silver Nanoparticles}

The silver nanoparticles was analyzed using UV-Vis spectroscopy after 1 hour, 24 hours, 48 hours, 72 hours, 96 hours, and 168 hours. The solution was then centrifuged. The size of the solution sample was determined by PSA.

\section{RESULT AND DISCUSSION Characterization of UV-VIS Spectrophotometers}

In general, the formation of silver nanoparticles is characterized by a change in the color of the solution from yellow to brown over time (Desna et. al., 2015). The color of the mixed solution consisting of $\mathrm{AgNO}_{3}$ and beluntas leaf extract was changed from clear to light yellow after 30 minutes of the stirring process. After 1 hour of stirring, the mixed solution undergone browning. The color become darker with the increase of the time.

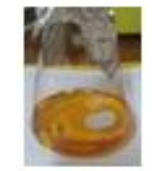

1 hour

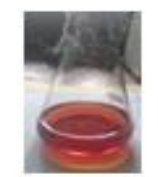

72 hours

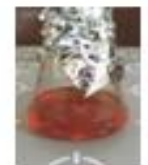

24 hours

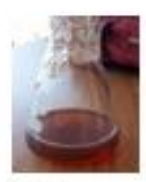

96 hours

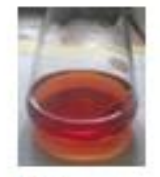

48 hours

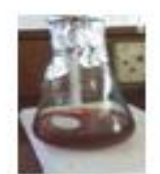

168 hours
Figure 2. Color change of Silver nanoparticles from 1 hour to 168 hours

From Figure 3 it can be seen that the absorbance value of each wavelength increases linearly with the increase in synthesis time from 1 hour to 168 hours but after 72 hours there is a shift in wavelength but the absorbance is only slightly increased. 


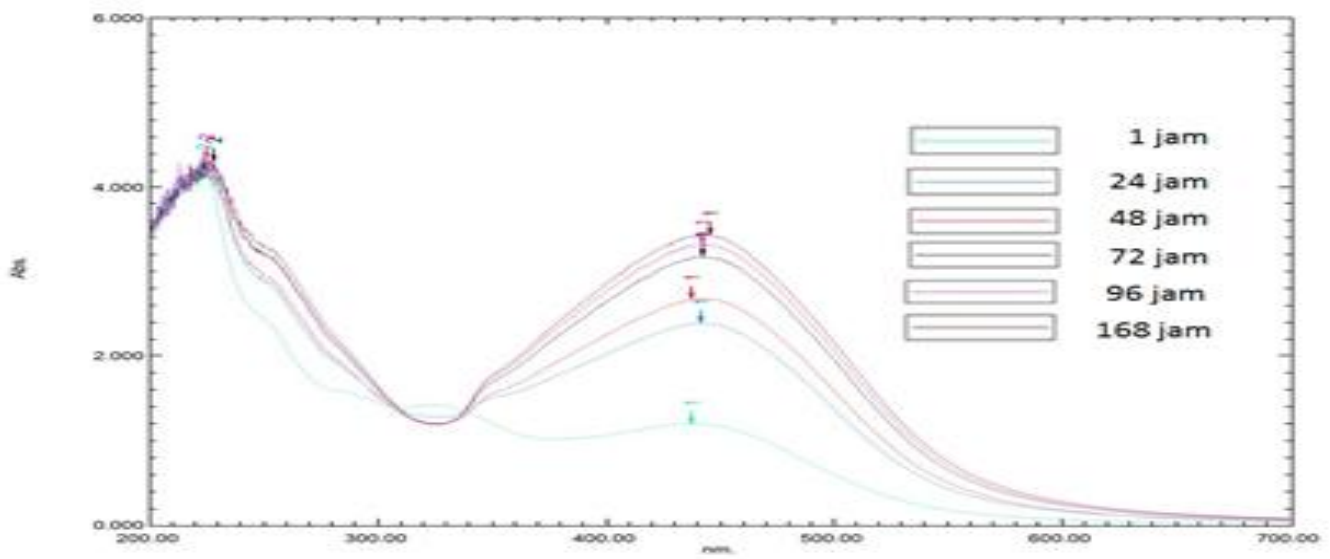

Figure 3. Spectra of UV-Vis from silver nanoparticles using beluntas leaf extract at various time intervals: 1 hour to 168 hours

Table 1. Wavelength data and absorbance of silver nanoparticles using beluntas extract.

\begin{tabular}{cccc}
\hline No. & $\begin{array}{c}\text { Time } \\
\text { (Hour) }\end{array}$ & $\begin{array}{c}\text { wavelength } \\
(\mathbf{n m})\end{array}$ & Absorbance \\
\hline 1. & 1 & 437,5 & 1,199 \\
2. & 24 & 441,5 & 2,394 \\
3. & 48 & 437,5 & 2,682 \\
4. & 72 & 442,5 & 3,185 \\
5. & 96 & 442,0 & 3,327 \\
6. & 168 & 445,5 & 3,437 \\
\hline
\end{tabular}

This shows that the synthesis process has stopped. The data in Table 1 also shows a shift in the wavelength of the SPR peak, which is from $437.5 \mathrm{~nm}$ to $445.5 \mathrm{~nm}$, which occurs with increasing synthesis time from
1 hour to 168 hours. From the data in Table 1 plotted the graph between the synthesis time and the absorbance value, as shown in Figure 4.

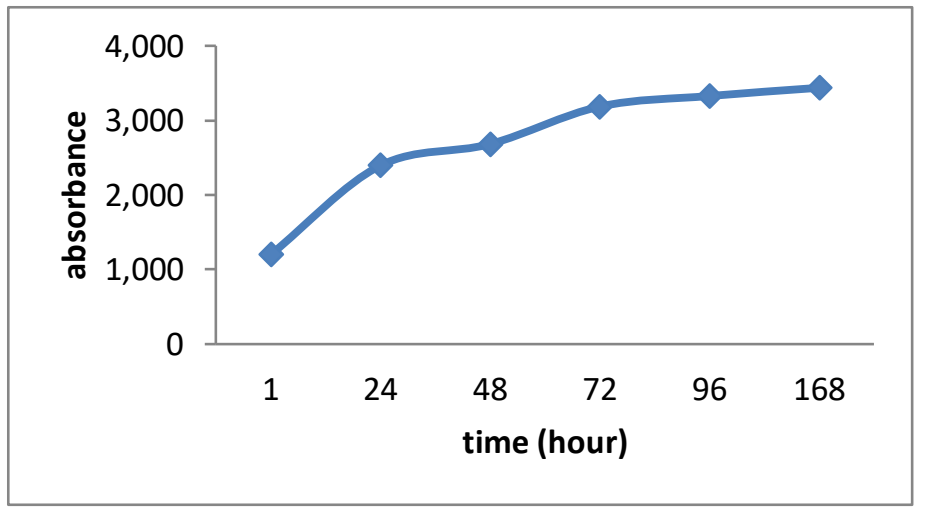

Figure 4. Graph of the absorbance of silver nanoparticles, at various time intervals: 1 hour to 168 hours.

With the increase in reaction time, the absorbance intensity increases until the reaction process stops, there is no increase in absorbance intensity anymore. 


\section{Characterization of PSA}

At PSA, particle size is measured based on dynamic light scattering. The motion of particles in the medium then correlates with the particle size possessed by silver nanoparticles. The laser beam

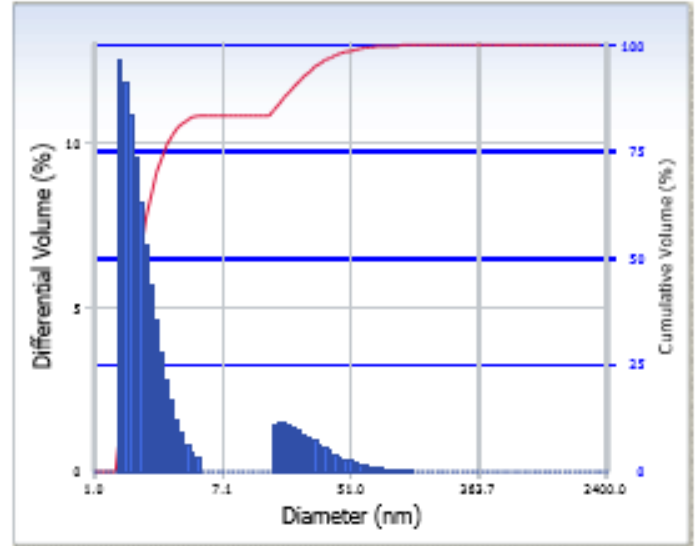

a. illuminated into the sample will experience intensity fluctuations due to particle light scattering (Wahab, et al., 2018). The size distribution of silver nanoparticles with beluntas extract using a PSA is shown in Figure 5.

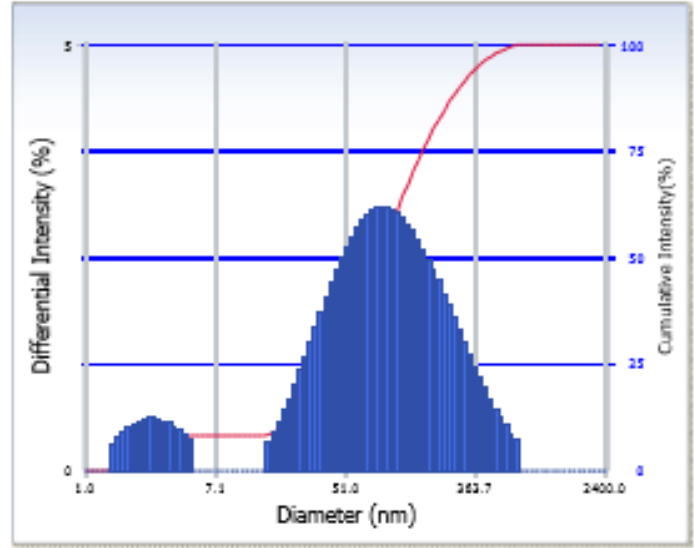

b.

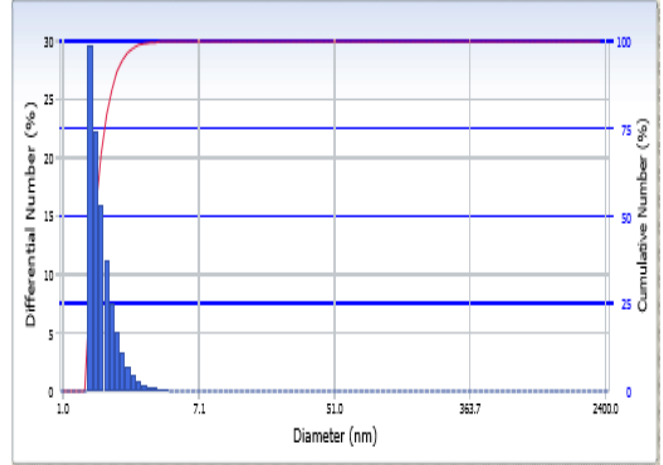

c.

Figure 5. Analysis of PSA of silver nanoparticles based on a. Dispersion size by intensity, b. Dispersion size by volume, c. Dispersion size by number

Figure 5 shows that the sample measured using PSA has the size of silver nanoparticles based on dispersion size by intensity was $127.3 \mathrm{~nm}$, by volume was 6.7 $\mathrm{nm}$, and by the amount was $1.8 \mathrm{~nm}$. Therefore the average size obtained was $109.1 \mathrm{~nm}$. This nanoscale size proves that beluntas leaf extract has the potential as a reducing agent in the manufacture of silver nanoparticles.

\section{CONCLUSION}

Based on the results mentioned above, it can be concluded that silver nanoparticles can be synthesized using beluntas leaf extract as a reducing agent. The maximum wavelength obtained using $\mathrm{UV}-\mathrm{V}$ is was $445.5 \mathrm{~nm}$ with the maximum absorbance of 3,437 . The average particle size measured by the PSA was $109.1 \mathrm{~nm}$ which was dispersed between $1.8 \mathrm{~nm}$ $127.3 \mathrm{~nm}$. 


\section{REFERENCES}

Anjum, S. and Abbasi, B. H., 2016, Thidiazuron-Enhanced

Biosynthesis And Antimicrobial Efficacy Of Silver Nanoparticles Via Improving Phytochemical Reducing Potential In Callus Culture Of Linum usitatissimum L., International Journal of Nanomedicine, 11 (2016): 715728.

Apriandanu, D., Wahyuni, S., Hadisaputro, S. and Harjono, 2013, Synthesis of Silver Nanoparticles Using the Polyol Method with Polyinilalkohol Stabilizing Agent (PVA), Journal of Mathematics and Natural Sciences, 36 (2): 157-168.

Desmiaty, Y., Puspitasari, A. and Zuhri, UM, 2015, Test of Xanthine Oxidase Inhibition Activity and Determination of Quercetin Levels Guava Leaf Extract (Psidium guajava L.) and Daun Beluntas (Pluchea indica Less.)., Published at the National Pharmacy University Seminar Jenderal Achmad Yani, Bandung.

Desna, M. L., Wellia, D. V. and Arief, S., 2015, Control of the Formation of Silver Nanoparticles through Capping Agents with the Aid of Bioreductor Gambir Leaf Extract (Uncaria gambir Roxb), Journal of Chemistry Unand, 4 (2): 18-22.

Fabiani, V. A., Sutanti, F., Silvia, D. and Putri, M. A., 2018, Green Synthesis Silver Nanoparticles Using Pucuk Idat Leaf Extract (Cratoxylum glaucum) as Bioreductor, Indo. J.Pure App. Chem., 1 (2): 68-76.

Kumar, H. and Rani, R., 2013, Structural

Characterization of Silver Nanoparticles Synthesized by Micro emulsion Route, International Journal of Engineering and Innovative Technology (IJEIT), 3 (3): 344-348. Shameli, K., Ahmad, M. B., Zamanian, A., Sangpour, P., Shabanzadeh, P.,
Abdollahi, Y. and Zargar, M., 2012, Green Biosynthesis of Silver Nanoparticles using Curcuma longa tuber powder, International Journal of Nanomedicine, 7 (2012): 5603-5610.

Terenteva, E. A., Apyari, V. V., Dimitrienko, S. G. and Zolotov, Y. A., 2015, Formation of Plasmonic Silver Nanoparticles by Flavonoid reduction: A comparative Study and Application For Determination of These Substances, Spectrochimica Acta Part A, 151 (2015): 89-95.

Wahab, A. W., Karim, A., Asmawati dan Sutapa, I. W., 2018, Bio-synthesis of Gold Nanoparticles Through Bioreduction Using the Aqueous Extract of Muntingia calabura $L$. Leaves, Oriental Journal of Chemistry, 34 (1): 401-409.

Widyawati, P. S., Wijaya, C. H., Hardjosworo, P. S. and Sajuthi D., 2008, Evaluation of Antioxidative Activity of Beluntas Leaf Extract (Pluchea Indica) Based on the Difference of Leaf Section, Faculty of Agricultural Technology - Unika Widya Mandala, Surabaya. 